\title{
Vennootschapsbelasting: de positie van België in het verruimde Europa
}

\author{
Hylke Vandenbussche ${ }^{(a)}$ en Karen Crabbé ${ }^{(b)}$
}

(a) Hoogleraar Faculteit Economische en Toegepaste Economische Wetenschappen,

$$
\text { K.U.Leuven }
$$

(b) Doctoraatsstudent Faculteit Economische en Toegepaste Economische Wetenschappen,

$$
\text { K.U.leuven }
$$

april 2005

\begin{abstract}
In deze studie vergelijken we de vennootschapsbelastingdruk van grote bedrijven in België in het verruimde Europa. De belastinghervorming in België van 2002 verlaagde de officiële aanslagvoet van 40.17\% in 1993 naar 33.99\%, waardoor België naar de achtste plaats zakt in de rangschikking van de EU25 volgens dalende vennootschapsbelasting. Toch blijft België na de hervorming in de top drie van de landen met de hoogste feitelijke belastingdruk in de EU25 in 2003. Dit betekent dat de Belgische feitelijke belastingdruk $8.36 \%$ boven het EU-gemiddelde uitsteekt in 2003 en in 2004 is de officiële aanslagvoet nog 7.1\% hoger dan het EU-gemiddelde. Door een strategie van verlaging van het officiële tarief en verbreding van de belastbare basis, blijft de feitelijke belastingdruk voor grote vennootschappen in België nagenoeg ongewijzigd. Bovendien vinden we dat de buurlanden van de nieuwe lidstaten een snellere daling in hun officiële aanslagvoet kenden dan niet-buren. Met andere woorden de directe buurlanden van Oost-Europa ondervinden meer belastingconcurrentie en staan onder meer druk om hun belastingtarief te verlagen. Op die manier is er geografisch gezien momenteel een 'centrumperiferie' ontstaan waarbij de centrum landen in de EU25 een 'belastingpremie' blijven vragen van ongeveer $15 \%$ punten.
\end{abstract}

JEL classificatie: H25, F15, M41, R12

Trefwoorden: Vennootschapsbelasting, Effectieve belastingdruk, belastinghervormingen, centrum-periferie theorie

Adres voor correspondentie: Hylke Vandenbussche, FETEW, Naamsestraat 69, 3000 Leuven, T: 0163269 20, hylke.vandenbussche@econ.kuleuven.be 


\section{Inleiding}

De voorbije 15 jaar is het gemiddelde statutaire vennootschapsbelastingtarief van de 25 Europese landen gedaald van 40.27\% in 1990 naar 26.8\% in 2004. Vooral met het oog op de toetreding van 10 nieuwe lidstaten hebben verschillende landen drastische hervormingen doorgevoerd. De meeste nieuwe lidstaten hebben immers niet alleen een loonvoordeel, ze hebben ook een relatief lage vennootschapsbelasting. In 2001 daalde het statutaire tarief in Duitsland van 51.63\% naar 39.36\% ${ }^{1}$. In 2000 bedroeg het gemiddelde statutaire tarief voor de vennootschapsbelasting in de EU15 34.96\% tegenover $25.96 \%$ in de 10 nieuwe lidstaten. Door de verschillende belastinghervormingen daalde het verschil in het vennootschapsbelastingtarief tussen de EU15 en de EU10 van 10.87\% punten in 1990 naar 6.9\% punten in 2002. Maar ook de nieuwe lidstaten zien het belang in van een lage vennootschapsbelasting en verlaagden recent hun statutaire tarieven zodat het verschil in belastingtarieven met de EU15 weer gestegen is tot 9.84\% in 2004. Ook België verlaagde haar officiële aanslagvoet van $40.17 \%$ naar 33.99\% met ingang van 2003. Onze berekeningen wijzen uit dat het effect van deze verlaging op de effectieve belastingdruk in 2003 nauwelijks merkbaar is. De effectieve belastingdruk daalde met minder dan 1\% punt van 30.8\% in 2002 naar 29.9\% in 2003. De meeste landen in Europa hebben naast een algemene trend van verlaagde statutaire tarieven, een verbreding van de belastbare basis doorgevoerd om het voor de schatkist budgettair neutraal te houden.

Om een 'race-to-the-bottom' te voorkomen, werkt de Europese Commissie aan een reeks voorstellen om de vennootschapsbelasting in de Europese Unie te harmoniseren. In oktober 2001 stelde de Europese Commissie de 'EU-conduct' voor waarin ze beschreef welke belastingsmaatregelen van individuele lidstaten een obstakel vormen voor de interne handel. Bovendien werkt ze aan een voorstel van een uniforme belastbare basis en een uniform tarief. Vooral Duitsland dringt aan op een uniform vennootschapsbelastingtarief en belastbare basis in de EU. Door zijn geografische ligging is Duitsland het meest onderhevig aan de concurrentie van de nieuwe lidstaten en staat onder druk om het belastingtarief te verlagen. Verschillende economen zoals Becker e.a. (2005) bevestigen dat één van de belangrijkste determinanten van de locatie keuze van bedrijven de geografische afstand is tot het thuisland. Onze resultaten tonen aan dat directe buren van de nieuwe Centraal- en Oost-Europese lidstaten hun statutaire belastingtarief sneller verlaagden dan niet-buren. Bovendien tekent er zich een 'core' gebied af met de 'buren' en 'nietburen', en een 'perifere' regio met Ierland, Portugal en de nieuwe EU10, waarbij de gemiddelde STR van de 'core' 15\% hoger is dan de 'periferie'. 
De indeling van dit artikel is als volgt: In een eerste deel bekijken we de rangschikking van de EU landen volgens hun statutaire belastingsvoet (STR) en volgens hun effectieve belastingdruk (ETR). In deel 2 kijken we naar de evolutie over de tijd heen in periode 1990-2004 van de STR en ETR. In een derde deel onderzoeken we het effect van de belastinghervorming van 2002 in België op de effectieve belastingdruk. Tenslotte onderzoeken we de invloed van de afstand tot de nieuwe lidstaten op de daling in STR van de EU15.

\section{Rangschikking van EU landen volgens STR en ETR}

\section{a. De Statutaire Aanslagvoet}

In dit eerste deel documenteren we de relatieve positie van België in termen van statutaire en effectieve vennootschapsbelastingdruk voor grote bedrijven in het 'oude' en het 'nieuwe' Europa. Het 'oude’ Europa verwijst naar de 15 EU lidstaten die al lid waren voor januari 2004 (België, Nederland, Luxemburg, Frankrijk, Italië, Verenigd Koninkrijk, Ierland, Spanje, Griekenland, Portugal, Denemarken, Zweden, Duitsland, Oostenrijk, en Finland). Met het nieuwe Europa bedoelen we de 25 EU lidstaten, waarvan er 10 lidstaten recent toetraden in 2004. De nieuwe toetreders bestaan uit de voormalige landen van Centraal- en Oost-Europa (Tsjechische Rep., Estland, Letland, Litouwen, Slovenië, Slowakije, Polen, Hongarije, Malta, Cyprus). In een aantal landen, zoals in België is het systeem van de vennootschapsbelasting progressief, dwz dat de aanslagvoet afhankelijk is van de hoogte van de winst. Onze vergelijking van officiële belastingsvoeten tussen verschillende landen baseert zich op de tarieven van toepassing op grote ondernemingen die in de hoogste winstschijven zitten voor die landen met een progressief belastingssysteem. In Tabel 1 tonen we welke landen een progressief systeem en welke een nietprogressief systeem ${ }^{3}$ hebben m.a.w. voor alle bedrijven eenzelfde aanslagvoet hanteren. ${ }^{4}$

In Figuur 1 tonen we voor het verruimde Europa van de EU25 voor elk land de officiële belastingsvoet (STR) en de gemiddelde feitelijke belastingsvoet (ETR). ${ }^{5}$ De landen staan in volgorde van dalende STRs. Hieruit blijkt dat anno 2004, Duitsland het land is met de hoogste officiële aanslagvoet (STR) namelijk 39.58\%, terwijl Cyprus het land is met de laagste officiële aanslagvoet namelijk 10\%. België bekleedt een $8^{\mathrm{e}}$ plaats in termen van officiële aanslagvoet met een officiële aanslagvoet van 33.99\% (inclusief crisisbelasting). Als we de landen rangschikken in dalende volgorde van de feitelijke aanslagvoeten (ETR) dan zien we voor 2002 op Figuur 2 dat Italië de hoogste feitelijke belastingdruk heeft met een ETR van 51.5\% terwijl Ierland de laagste 
feitelijke belastingdruk heeft met een ETR van 2\%. België neemt hierbij de tweede positie in, na Italië met een ETR van ongeveer 30\%. Voor het berekenen van de gemiddelde feitelijke belastingdruk per land maken we gebruik van een pan-Europese dataset genaamd AMADEUS. Deze dataset bevat de jaarrekeningen van alle grote ondernemingen in Europa in een geharmoniseerd formaat, zodat een vergelijking over landen mogelijk wordt. De laatst beschikbare gegevens lopen echter maar tot 2003 en voor sommige landen tot 2002. Vandaar dat onze ETR gegevens maar tot 2002 gaan. Voor België bestaat er wel een tweede databank van Bureau Van Dijck, namelijk BELFIRST, waar wel ETR gegevens van 2003 beschikbaar zijn. De Belgische resultaten voor 2003 worden in deel drie apart besproken.

Op Figuur 1 maken we ook een vergelijking van de gemiddelde officiële en feitelijke belastingdruk per land. Hierbij valt op dat voor de meeste landen de ETR lager ligt dan de STR (uitzonderingen zijn Italië, Polen, Slowakije en Letland). Of m.a.w. dat de effectieve belastingdruk lager ligt dan wat de officiële aanslagvoet laat vermoeden. Voor België is het verschil tussen STR en ETR op deze Figuur tamelijk klein maar hierbij moeten we opmerken dat de STR van 33,99\% van nà de belastingdaling in december 2002 dateert, terwijl de ETR van 30,8\% van vóór de belastingdaling van 2002 dateert. Op dit moment ligt de ETR vermoedelijk lager dan wat er op Figuur 1 te zien is. Voor andere landen is het verschil tussen STR en ETR groter zoals voor de Tsjechische Republiek met een officieel tarief in 2004 van 28\% en een feitelijk tarief van amper 2,4\%. Er zijn ook landen waar de ETR groter is dan de STR. Italië bijvoorbeeld heeft een STR van 38,25\% in 2004 en een ETR in 2002 van 51,5\% en ook Polen, Slowakije en Letland, zijn landen waar de effectieve belastingdruk hoger is dan wat de officiële aanslagvoet aangeeft.

In Tabel 2 rangschikken we de landen volgens officiële aanslagvoet. We doen dit voor verschillende jaren waar we een vergelijking maken met de rangschikking in het begin van de jaren negentig en in het begin van de jaren 2000. Telkens duiden we de positie van België in het vet aan. We beginnen in kolom 1 met het 'oude Europa' van de EU15 waar we de officiële tarieven vergelijken in 1993. België bekleedde in 1993 de derde plaats in deze lijst, na Duitsland en Italië met een STR van 40,17\% ${ }^{6}$. In de tweede kolom van Tabel 2 geven we de positie van België weer in het ‘nieuwe’ Europa van de EU25 in het jaar 2002. Daar zien we dat België één plaats naar boven is opgeschoven en op de tweede plaats prijkt waar het enkel Italië moet laten voorgaan als land dat een nog hogere STR had. In kolom drie krijgen we de meest recente beschikbare rangschikking te zien in 2004 en daar zakt België met zijn 33,99\% ${ }^{7}$ naar de achtste plaats, dankzij de verlaging van de STR die de regering Verhofstadt besliste op het einde van 2002. 
Terwijl de positie van België tot voor 2002 niet veel veranderde binnen de EU, is dit evenmin het geval voor een aantal andere landen, zoals Italië, Duitsland, Frankrijk, Nederland, Spanje, en Zweden. Echter, voor andere landen is de rangschikking in termen van officiële belastingsvoeten wel gevoelig gewijzigd. Ierland is hiervan een uitgesproken voorbeeld: waar Ierland in 1993 nog de vierde hoogste officiële belastingsvoet had, staat Ierland in 2004 helemaal onderaan de lijst met een tarief van $12.5 \%$ net voor Cyprus, dat met $10 \%$ op dit moment het land is met de laagste STR van het hele 'nieuwe' Europa. Duitsland, het land dat een belangrijke aanzet gegeven heeft tot een algemene verlaging van de STRs in Europa door in het jaar 2001 een belangrijke verlaging door te voeren en daarmee in kolom 2 van Tabel 2 op een derde positie in de EU stond maar omwille van andere landen die het voorbeeld van Duitsland volgden en ook hun officieel verlaagden, staat Duitsland uiteindelijk in 2004 terug op kop als land met hoogste officiële aanslagvoet, zoals we kunnen zien in kolom 3 van Tabel 2 waar we alle EU25 landen van het verruimde Europa rangschikken in termen van STR.

De nieuwe toetreders in de EU staan helemaal onderaan de lijst in termen van officiële belastingsvoeten waarbij de 'duurste’ voormalige Oostbloklanden Estland en Slovenië zijn met een officieel winsttarief van respectievelijk $26 \%$ en $25 \%$ in 2004, terwijl de 'goedkoopste' nieuwe lidstaten, de Baltische staten Litouwen en Letland zijn met beiden een tarief van 15\% en Cyprus met een officieel tarief van winstbelasting van 10\%. De meeste nieuwe lidstaten hebben ondertussen een vlaktaks ingevoerd die één aanslagvoet heft op alle inkomsten (personen- en vennootschappen) en alle aftrekposten afschaft. Deze tendens is begonnen in 1994 met Estland en sindsdien zijn ook Letland, Litouwen, Rusland, Slowakije en Roemenië omgeschakeld naar een vlaktaks. In andere landen zoals Polen, Nederland en de VS woedt het debat over de vlaktaks in alle hevigheid (Trends, 2005).

\section{b. De Effectieve Belastingdruk}

In kolom 4 en 5 van Tabel 2 krijgen we een rangschikking van België in termen van de feitelijke belastingdruk (ETR). De 'feitelijke' of 'effectieve belastingdruk' kan berekend worden door het bedrag dat een bedrijf effectief betaalt aan vennootschapsbelasting te relateren aan de belastingsbasis. Ideaal zouden we hiervoor toegang moeten hebben tot de aanslagformulieren van het Ministerie van Financiën. Dit is echter geen publieke of commerciële informatie. Enkel het Ministerie van Financiën beschikt over de exacte cijfers. Als onderzoekers hebben we wél toegang tot de financiële staten van bedrijven. Daarin vinden we ondermeer het bedrag aan belastingen dat 
een bedrijf voorziet te moeten betalen alsook de winst waarop de belasting verschuldigd is. Als benadering van de effectieve belastingdruk gebruiken wij de resultatenrekening en relateren wij het bedrag van de 'Belastingen’ aan de ‘Winst voor Belastingen'.

De belastingadministratie gebruikt de 'Winst voor belastingen' als een startpunt om de belastbare basis te berekenen maar kan bepaalde uitgaven van de firma verwerpen als kost, waardoor de belastbare basis groter wordt en de te betalen belasting eveneens stijgt (Van Kerckhove en Heirewegh, 2003). Het bedrag van 'Belastingen’ dat we terug vinden op de resultatenrekening is daarom eerder een benadering van de uiteindelijk verschuldigde belastingen aan de overheid. Bovendien kan het zijn dat het bedrag van 'Belastingen' dat we terug vinden op de resultatenrekening ook nog een deel achterstallige belastingen inhoudt. Onze berekening van de Effectieve belastingvoet is echter een algemeen aanvaarde maatstaf en wordt in de literatuur ook wel eens genoemd de 'backward looking Effective Tax Rate’ (Plesko, 2003; Buijink et al. 2002, 2000, Nicodème 2001). ${ }^{8}$

Belangrijk is dat de feitelijke belastingvoet lager kan zijn dan de officiële belastingvoet omdat de belastbare basis tussen landen kan verschillen. Neem het volgende voorbeeld om dit te illustreren. Als we twee landen hebben met een gelijkaardige officiële belastingvoet maar waarvan het ene land veel aftrekken toelaat, d.w.z. waar veel bedrijfsuitgaven als kost mogen in mindering gebracht worden van de opbrengsten, terwijl het andere land weinig aftrekken toelaat. Dan zal het eerste land in dit voorbeeld een lagere feitelijke belastingvoet hebben dan het tweede land omdat de belastbare basis in het eerste land lager zal zijn dan in het tweede land.

In kolom 4 van Tabel 2 tonen we de gemiddelde feitelijke belastingdruk ( ETR) voor de landen in Europa in 1993. In kolom 5 doen we hetzelfde maar dan voor het jaar 2002. In kolom 4 zien we dat de gemiddelde feitelijke aanslagvoet voor België in 1993 op 30,3\% lag, waarmee België de tweede hoogste ETR in de EU15 had. In 2003, het meest recente jaar waarvoor we Belgische ETR data hebben, was België met 29,9\% nog altijd het land met de derde hoogste feitelijke belastingdruk na Italië en Nederland, terwijl Ierland in 2002 het land is met de laagste feitelijke druk van 2\%, die zelfs beneden de feitelijke belastingdruk van alle nieuwe toetreders ligt.

Aan de hand van Tabel 2 zien we dat de officiële aanslagvoeten (STR) over de tijd heen eerder een dalende trend vertonen, terwijl de feitelijke aanslagvoeten (ETR) van de verschillende landen een stijgende trend vertonen, vaak met een hogere waarde in 2002 dan in 1993. Spanje bijvoorbeeld had in 1993 een ETR van 14,4\% en kon zich bij de landen rekenen met de laagste ETRs, terwijl in 2004 
de Spaanse ETR steeg naar 25,2\%. Dit terwijl de STR in die periode onveranderd bleef op ongeveer 35\%. Dit kan maar één ding betekenen, namelijk dat Spanje in deze periode overging tot een vergroting van de belastbare basis. Hetzelfde kan gezegd worden over ondermeer Oostenrijk en Denemarken en ook andere landen, zij het in mindere mate.

In Tabel 2 valt ook op dat de gemiddelde officiële aanslagvoet voor heel Europa sterk gedaald is. Onderaan kolom 1 in Tabel 2 vinden we de gemiddelde STR van het 'oude’ Europa in 1993 die gelijk was aan 38,51\%. Onderaan kolom 3 vinden we de gemiddelde STR van het 'nieuwe' verruimde Europa in 2004 dat gelijk is aan 26,8\%. Dus m.a.w. de gemiddelde STR is gedaald met ongeveer $10 \%$ punten van 38, 51\% naar 26,85\%. De standaard deviatie, die de mate aangeeft waarin de landen korter of verder uit elkaar liggen, is gestegen. Dit suggereert dat in het nieuwe Europa de STRs gemiddeld lager zijn dan de jaren voordien en verder uit elkaar liggen dan in het oude Europa. Als we de nieuwe toetreders apart als groep nemen zien we dat de gemiddelde STR voor de 10 nieuwe toetreders in 2004 gelijk is aan 20,8\%. Opvallend daarbij is dat alle nieuwe lidstaten in het jaar van hun toetreding namelijk in 2004 hun STRs lieten dalen. De enige twee uitzonderingen hierop zijn Estland en Slovenië.

Terwijl de gemiddelde STR in Europa op 10 jaar tijd gedaald is met ongeveer $10 \%$ punten, is de gemiddelde feitelijke belastingsvoet (ETR) maar licht gedaald van 22,83\% naar 21,59\%. Dit zien we door een vergelijking van de gemiddelde ETR in 1993 onderaan kolom 4 in Tabel 2 met de gemiddelde ETR in 2002 onderaan kolom 5 in Tabel 2. Dus hoewel de officiële aanslagvoeten in Europa een dalende tendens vertonen, zijn de ETRs relatief stabiel gebleven over de tijd heen. Dit lijkt erop te wijzen dat er sprake is van een algemene 'broekzakvestzak operatie' waar de daling van de belastingvoet gecompenseerd werd door de vergroting van de aanslagbasis zodat de gecollecteerde vennootschapsbelastingen ongeveer gelijk zijn gebleven. Dit bevestigt de resultaten van Devereux, Griffith en Klemm (2002) die vinden dat de effectieve belastingdruk stabiel bleef voor de periode 1980-1990 door het tegelijkertijd verbreden van de belastbare basis en verlagen van de STR.

\section{De Evolutie over de tijd van STRs en ETRs voor de EU landen}

Vervolgens bekijken we de evolutie over de tijd heen van de officiële (STR) en de feitelijke aanslagvoeten (ETR) voor het voorbije decennium. 
$\underline{\text { In Figuur } 3}$ bekijken we de evolutie van de gemiddelde STR tussen 1990-2004, van het 'oude' Europa (EU15) en de 'nieuwe toetreders'. Hierbij valt op dat er een duidelijke daling van de gemiddelde STR aan de gang is binnen het 'oude’ Europa, maar de daling binnen de groep van de toetreders is nog groter geweest. De daling van STRs binnen de nieuwe EU10 is versneld ingezet op het einde van de jaren '90. De enige landen in de groep van de EU10 die tot 2004 geen daling van STRs doorvoerden zijn Estland en Slovenië. Maar Estland heeft in 1994 een vlaktaks ingevoerd met economisch succes als gevolg en Slovenië overweegt een substantiële belastinghervorming in 2005. Wat ook opvalt, is dat het verschil in gemiddelde STR tussen het 'oude' en het 'nieuwe' Europa sterk vergroot is. Waar dit verschil halverwege de jaren '90 nog geen 2,5\% punten bedroeg, was dit op het eind van de jaren '90 gestegen tot ongeveer een 5\% punten, terwijl in 2004 de gemiddelde STR van de nieuwe toetreders bijna 10\% lager ligt dan de gemiddelde STR van het 'oude' Europa. M.a.w. de kloof binnen Europa tussen 'oud' en 'nieuw' Europa in termen van de officiële aanslagvoeten is vergroot.

In Figuur 4 tonen we dezelfde 2 datareeksen als in Figuur 3, maar we voegen de evolutie van de Belgische STR als een aparte reeks toe. Uit deze vergelijking blijkt duidelijk dat België t.o.v. het 'oude’ Europa een hogere dan gemiddelde STR heeft. Zelfs na de daling van de STR in december 2002 van 40,17\% naar 33,99\% blijft België boven het gemiddelde van het 'oude' Europa hangen. Voor 2002 heeft België lange tijd zijn STR op hetzelfde niveau gehouden, terwijl vanaf het midden van de jaren '90 de gemiddelde STR van het 'oude' Europa is beginnen dalen. Daardoor steeg het verschil in 2002 tot een recordhoogte waarbij de STR van België ongeveer 10\% punten hoger lag dan het gemiddelde van de rest van het ‘oude’ Europa. Na 2002 is dit verschil met het 'oude Europa teruggebracht tot ongeveer 3\% punten, terwijl het verschil tussen de Belgische STR en het gemiddelde van de nieuwe EU lidstaten ongeveer 13\% punten bedraagt.

$\underline{\text { In Figuur } 5}$ tonen we de evolutie tussen $1993-2002^{9}$ van de gemiddelde feitelijke belastingsvoeten van het 'oude' Europa en van de 'nieuwe' EU lidstaten als afzonderlijke groepen. Net zoals bij de STRs, ligt de gemiddelde ETR in het 'oude’ Europa voor alle jaren boven de ETRs van de 'nieuwe' lidstaten. In het jaar 2000 bedroeg dit verschil ongeveer 13\% punten, terwijl dit in het jaar 2002 gereduceerd is tot een gemiddelde ETR voor het 'oude' Europa die ongeveer 7\% punten boven de gemiddelde ETR voor de 'nieuwe' lidstaten ligt. Uit het verloop van de gemiddelde ETRs in beide groepen komt echter een heel ander beeld naar voren dan op basis van de evolutie van de STRs in Figuur 3. In tegenstelling tot de gemiddelde STRs, vertonen de gemiddelde ETRs een 'grilliger' verloop, voornamelijk in de groep van de nieuwe lidstaten. De trend van de gemiddelde ETR voor 
het 'oude' Europa is bijna over de hele lijn lichtjes stijgend, terwijl dit voor de 'nieuwe' lidstaten pas sinds eind jaren negentig het geval is. Opvallend is dat de periode van stijgende ETRs in de nieuwe lidstaten samenvalt met de periode van dalende STRs. Dit wijst erop dat ook in de nieuwe lidstaten de daling van de STRs gedeeltelijk gecompenseerd is geweest door een stijging van de belastbare basis.

$\underline{\text { In Figuur } 6}$ voegen we aan de 2 datareeksen van Figuur 5 nog de evolutie van de Belgische ETR toe. Wat opvalt, is dat de feitelijke belastingdruk in België zeer stabiel over de tijd is geweest. We zien ook duidelijk dat België in termen van ETR boven het gemiddelde van het 'oude' Europa prijkt. Het verschil tussen België en het oude Europa is wat verkleind maar voornamelijk doordat de gemiddelde ETR van het 'oude’ Europa gestegen is. Toch blijft de Belgische ETR substantieel boven het gemiddelde van het 'oude' Europa liggen met ongeveer 8.36\% punten in 2003. Met de 'nieuwe' lidstaten is het verschil in ETR nog een stuk groter en daar ligt België ongeveer 15\% punten boven in 2002.

\section{De ETR na de belastinghervorming van 2002 in België}

Om het Belgische belastingtarief in de buurt van het Europese gemiddelde te brengen en de fiscale voordelen voor KMO's te vergroten, voerde de regering op 24 december 2002 een belastinghervorming door. Vanaf aanslagjaar 2004 (boekjaar 2003) bedraagt het statutaire tarief 33.99\%, maar tegelijk werden ook bepaalde aftrekmogelijkheden en fiscale regimes beperkt. Bijvoorbeeld het verlaagde tarief voor buitenlandse inkomsten wordt afgeschaft en verschillende gewestbelastingen en heffingen zijn niet meer aftrekbaar waardoor de belastbare basis vergroot. Op basis van de databank BELFIRST (2004) kunnen we de effectieve belastingdruk van 2003 berekenen. We beschikken hiervoor over 2841 Belgische bedrijven met een winst voor belasting groter dan 322261.59 euro $^{10}$.

Figuur 7 geeft de evolutie weer van de gemiddelde ETR in België over de tijd. We zien duidelijk een stijging van de gemiddelde ETR in België tot een hoogtepunt van 31.22\% in 2001. Daarna daalt de gemiddelde ETR terug tot $29.88 \%$ in 2003. Dit betekent een daling van slechts $0.95 \%$ ten opzichte van 2002 en een daling van $0.40 \%$ ten opzichte van 1993. Vandenbussche, Janssen en Crabbé (2005) argumenteerden reeds eerder dat de feitelijke belastingdruk voor grote Belgische bedrijven het sterkst geweest is onder Verhofstadt I. Zij spreken van een anticipatie-effect: in de 
jaren voor de verlaging van de vennootschapsbelasting werd de belastbare basis uitgebreid om het budgettaire effect in de overheidsinkomsten te neutraliseren.

In de rangschikking van Tabel 2 betekent dit dat België in 2003 nog steeds tot de top drie behoort van de landen met de hoogste effectieve belastingdruk. Alleen Italië en Nederland hebben een hogere gemiddelde belastingdruk. Tegenover 1993 is er wel een daling in de rangschikking, maar de recente Belgische ETR zit nog steeds hoog boven het EU-gemiddelde.

\section{Is de daling in STR groter geweest in de buurlanden van de 'nieuwe' lidstaten?}

Een mogelijkheid die we hier willen bekijken is dat landen uit het 'oude' Europa die geografisch dicht bij de nieuwe lidstaten liggen waarschijnlijk meer directe concurrentie van lage vennootschapsbelastingvoeten ervaren dan de wat verder afgelegen landen en zodoende wellicht meer onder druk staan om hun STR te verlagen.

Wanneer we de individuele landen in de groep van het 'oude' Europa meer in detail bekijken valt het op dat er een set van landen is die een aantal drastische verlagingen van de STR hebben doorgevoerd, terwijl er een andere set van landen is waarvoor de STR vrij onveranderd over de tijd is gebleven. Op het eerste zicht lijkt het alsof de landen die in de geografische nabijheid van de 'nieuwe' lidstaten liggen een grotere daling gekend hebben dan de andere landen die er verder van verwijderd zijn. Om dit verder te onderzoeken splitsen we de landen in het 'oude' Europa op in ‘Buren’ versus ‘Niet-Buren' van de nieuwe lidstaten, waarbij het criterium om tot de 'Buren’ van de nieuwe lidstaten te behoren een gezamenlijke landgrens of gezamenlijke waters met de nieuwe lidstaten, is. Een kaart van het verruimde Europa in Figuur 8 laat zien welke landen hieronder vallen. Zo bijvoorbeeld heeft Finland geen landgrens met de Baltische Staten maar Finland heeft het wel een 'watergrens’ met deze landen. De groep van de 'Buren’ bestaat uit Duitsland, Oostenrijk,

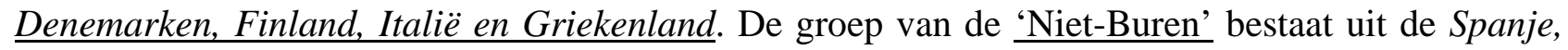
Frankrijk, Verenigd Koninkrijk, Nederland, België, Zweden en Noorwegen. Daarnaast nemen we de meest perifere gebieden zoals Ierland en Portugal als een aparte groep.

$\underline{\text { In Figuur } 9}$ tonen we het verloop van de STR voor de groep van 'Buren', 'Niet-Buren' en 'Perifere landen’ t.o.v. de nieuwe EU10 landen. Hierbij vallen ons twee zaken op. Ten eerste, voor de 'Buren' was de gemiddelde STR begin jaren '90 de hoogste van alle landen binnen het 'oude' Europa. Ten tweede, zien we duidelijk dat de daling in STR over de tijd heen sneller gegaan is bij de 'Buren' van de nieuwe EU10 dan bij de Niet-Buren, die tot dusver veel minder verandering van 
de STRs gekend hebben. De sterkste daling in STR is echter op te merken bij de meest 'perifere' landen van de EU namelijk Ierland en Portugal.

$\underline{\text { In Figuur } 10}$ voegen we daar nog het verloop van de gemiddelde STR van de EU10 aan toe. Wat daarbij opvalt is dat de 'Buren van de EU10, die een sterkere daling van de STR kenden dan de 'Niet-Buren', geconvergeerd zijn naar het niveau van de 'Niet-Buren. Daarnaast valt op dat de meest 'perifere landen van het oude Europa' nl. Ierland en Portugal hun STR hebben laten dalen tot op het niveau van de nieuwe EU10. Er tekent zich als het ware een 'core' regio af die bestaat uit de 'buren’ en ‘niet-buren’ en een 'perifere’ regio bestaande uit de nieuwe EU10 en de perifere landen uit het 'oude' Europa met name Ierland en Portugal. Tussen de 'core' en de 'periferie' in het nieuwe Europa blijkt er niet directe convergentie te zijn. De 'core' blijft dus voorlopig een extra 'STRpremium' vragen. Dit is in lijn met de theorie van Baldwin and Krugman (2002). Op basis van onze data zien we op Figuur 9 dat het verschil tussen de gemiddelde STR in de 'core-landen' en in de 'periferie-landen'

ongeveer $15 \%$ punten bedraagt

in 2004. 


\section{$\underline{\text { Besluit }}$}

In dit artikel vergelijken we de vennootschapsbelastingdruk van grote bedrijven in België in het verruimde Europa. We zien dat de gemiddelde statutaire belastingvoet (STR) in Europa in 10 jaar tijd gedaald is met $10 \%$ in tegenstelling tot de feitelijke belastingdruk (ETR) die redelijk stabiel gebleven of zelfs gestegen is over de tijd. Dit betekent dat de belastinghervormingen van het laatste decennium een strategie zijn van verlaagde STR en een vergroting van de belastbare basis. België zakt na de belastingverlaging van 2002 naar de achtste plaats in de rangschikking van landen met het hoogste tarief. Maar de effectieve belastingdruk blijft ook in 2003 8.36\% boven het gemiddelde van de EU uitsteken. België zit bij de top drie van landen met de hoogste effectieve belastingdruk in de EU. Alleen Italië en Nederland hebben een hogere effectieve belastingdruk.

Tenslotte bekeken we of landen uit het 'oude’ Europa die geografisch dicht bij de nieuwe lidstaten liggen meer directe concurrentie ervaren en onder meer druk staan om hun STR te verlagen. Uit onze analyses valt het op dat de 'buren', d.w.z. landen met een land- of zeegrens met de nieuwe lidstaten zoals Duitsland, Oostenrijk, Denemarken, Finland, Italië en Griekenland, een snellere daling van de STR kenden over de tijd dan bij de 'niet-buren' van de nieuwe EU10 en daardoor convergeren naar het STR-niveau van de 'niet-buren'. Bovendien kenden de meest 'perifere' landen van het 'oude’ Europa de sterkste daling in de STR in de voorbije 10 jaar. Als gevolg wordt er een ‘core’ en een 'periferie’ gebied gevormd binnen het nieuwe Europa. De 'core’ bestaat uit de 'buren' en 'niet-buren' en de 'periferie' bestaat uit Portugal, Ierland en de nieuwe lidstaten. De 'core' landen kunnen een hogere STR vragen zonder bedrijven te verliezen omwille van hun voordeel in infrastructuur en 'spillovers' door de aanwezigheid van andere bedrijven. Deze bevindingen bevestigen de Baldwin en Krugman (2002) theorie. Deze theorie stelt dat landen met een geografisch nadeligere positie in staat moeten zijn hun belastingvoeten lager te zetten dan de landen met een geografisch interessantere locatie. Dus m.a.w. belastingharmonisatie is niet nodig, de markt zal zelf wel bepalen welke belastingvoet voor elk land het meest optimaal is. Belastingdifferentiatie biedt een instrument aan voor minder aantrekkelijke landen om toch bedrijven te kunnen aantrekken. Echter de 'core' regio zou zich in dynamische context relatief snel kunnen verleggen, dus alertheid is geboden voor overheden bij het kiezen van de 'juiste belastingvoet'. De Nederlandse regering keurde recent een verlaging van de vennootschapsbelasting van 34.5\% naar 26.9\% in 2007 goed (De Tijd, 2005). En ook Duitsland denkt eraan de vennootschapsbelasting te laten dalen om de hoge werkloosheid tegen te gaan (Financial Times,2005). Voor België bestaan er vooralsnog geen concrete plannen om de winstbelasting verder te verlagen. Door als eerste land in 
Europa dit jaar nog een aftrek voor risicokapitaal in te voeren, hoopt ons land alsnog fiscaal aantrekkelijker te worden. De toekomst zal uitwijzen of deze maatregel vooralsnog zal volstaan om de belastingconcurrentie van de overige EU-24 het hoofd te kunnen bieden. 
Tabel 1: Progressief systeem van Vennootschapsbelasting of Niet-progressief systeem

\begin{tabular}{|c|c|}
\hline Progressief systeem & Niet-progressief systeem \\
\hline Cyprus & Tsjechië \\
\hline België & Estland \\
\hline Frankrijk & Hongarije \\
\hline Nederland & Malta \\
\hline Portugal & Polen \\
\hline Spanje & Slowakije \\
\hline \multirow[t]{13}{*}{ VK } & Slovenië \\
\hline & Oostenrijk \\
\hline & Denemarken \\
\hline & Finland \\
\hline & Duitsland \\
\hline & Griekenland \\
\hline & lerland \\
\hline & Italië \\
\hline & Luxemburg \\
\hline & Noorwegen \\
\hline & Zweden \\
\hline & Letland \\
\hline & Litouwen \\
\hline
\end{tabular}

Bron: KPMG corporate tax surveys, www.worldwide-tax.com

opm.: niet-progressief systeem = een zelfde statutaire aanslagvoet voor alle bedrijven ongeacht de belastbare basis 


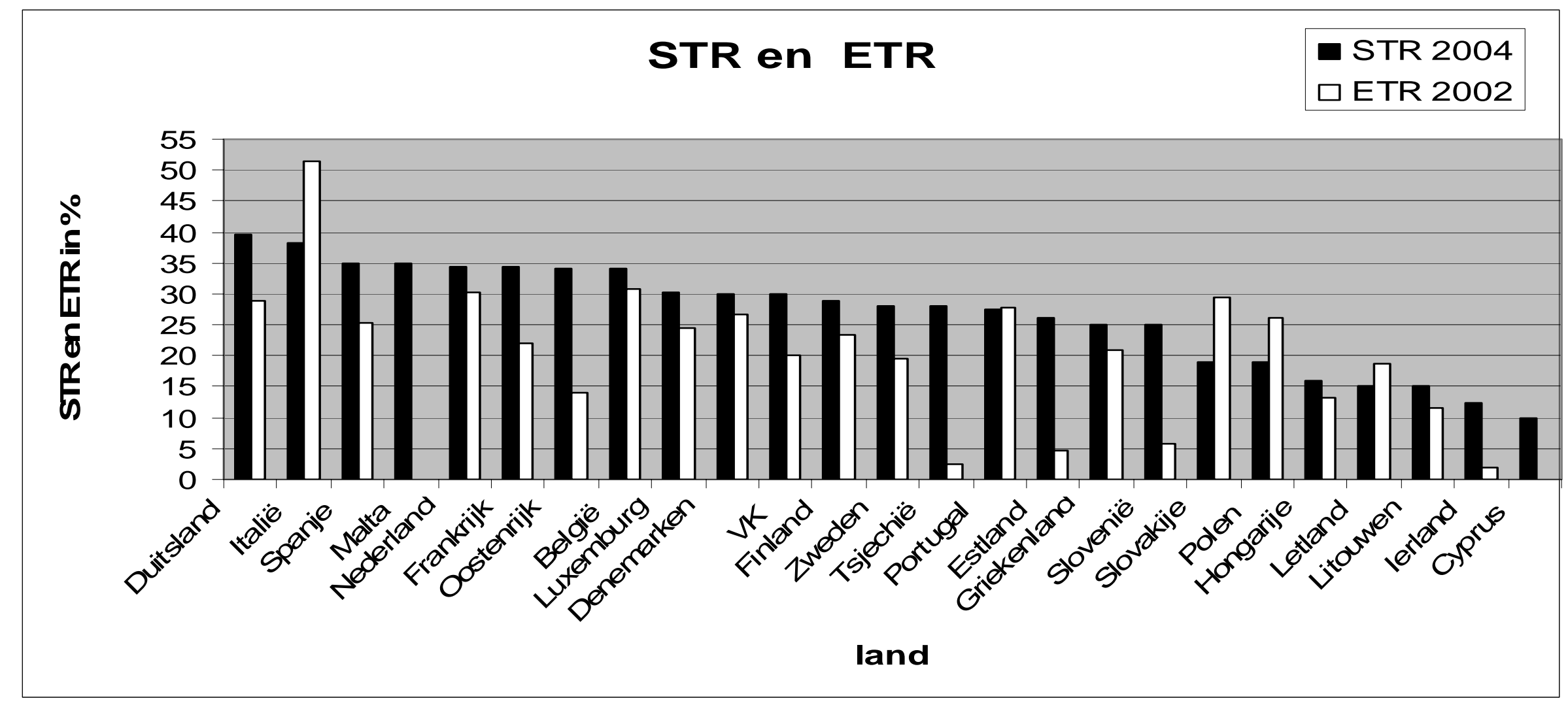

opm.: 1) ETR= Belastingen/Winst voor Belasting, gebaseerd op firmagegevens van Amadeus 2004 en Slovenian National Company Accounting Data

2) STR= officiële winstbelasting ('Statutory Tax Rates') gebaseerd op Janssen (2003), KPMG rapporten en www.worldwide-tax.com

2) Als een land een progressief belastingsysteem heeft, gebruiken we de hoogste marginale aanslagvoet

3) We beschouwen enkel firma's met redelijke waarden voor de feitelijke belastingsvoet (ETRs $>1$ en ETRs $<0$ )

4) de feitelijke belastingsvoet (ETR) voor Oostenrijk is de 2001 waarde omdat de 2002 waarde niet kon berekend worden

5) de feitelijke belastingsvoeten (ETRs) voor Malta en Cyprus konden niet berekend worden en ontbreken 
Figuur 2: De Rangschikking van alle EU lidstaten volgens dalende orde van 'Effectieve Aanslagvoeten'

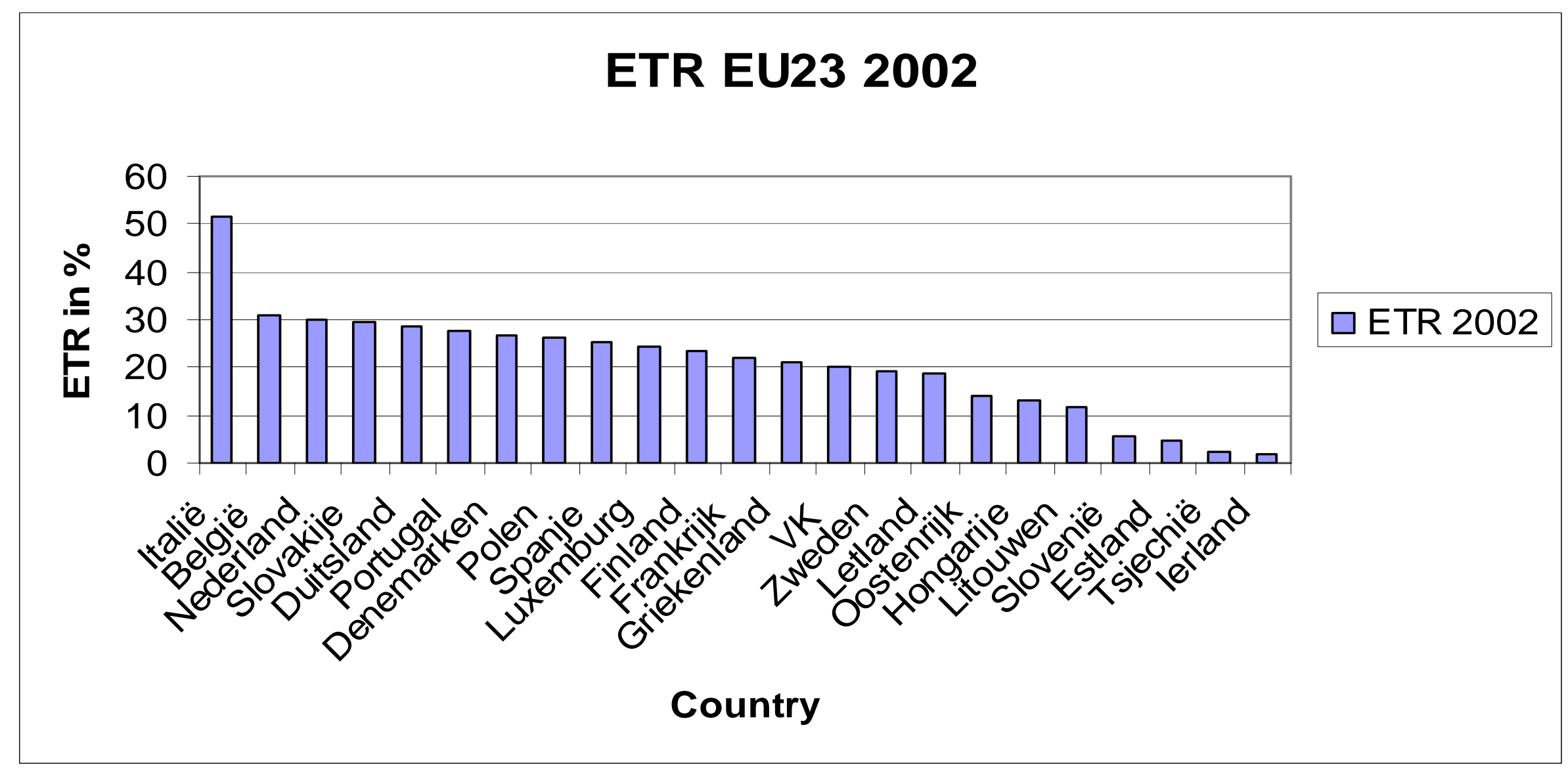

opm.: ETR voor Oostenrijk is de 2001 waarde omdat de 2002 waarde niet beschikbaar is; ETRs voor Malta en Cyprus zijn niet beschikbaar bron: Amadeus 2004 en Slovenian National Company Accounting data 
Tabel 2: Vergelijking van Aanslagvoeten van Vennootschapsbelasting over Europa (in \%)

\begin{tabular}{|c|c|c|c|c|c|c|c|c|c|c|c|}
\hline EU15 & $\begin{array}{l}(1) \\
\text { STR } \\
1993\end{array}$ & $E U 23^{a}$ & $\begin{array}{l}(2) \\
\text { STR } \\
2002\end{array}$ & EU25 & $\begin{array}{l}(3) \\
\text { STR } \\
2004\end{array}$ & EU15 ${ }^{\mathrm{c}, \mathrm{e}}$ & $\begin{array}{l}(4) \\
\text { ETR } \\
1993 \\
\end{array}$ & $E U 23^{b, d}$ & $\begin{array}{l}(5) \\
\text { ETR } \\
2002 \\
\end{array}$ & EU23 $3^{\mathrm{b}, \mathrm{d}, \mathrm{e}}$ & $\begin{array}{l}(6) \\
\text { ETR } \\
2003\end{array}$ \\
\hline \multirow{2}{*}{$\begin{array}{l}\text { Duitsland } \\
\text { Italië }\end{array}$} & 56.5 & Italië & 40.25 & Duitsland & 39.58 & Italië & 42.2 & Italië & 51.5 & Italië & 51.5 \\
\hline & 52.2 & België & 40.17 & Italië & 38.25 & België & 30.3 & België & 30.8 & Nederland & 30.2 \\
\hline België & 40.17 & Duitsland & 38.26 & Malta & 35 & Nederland & 28.9 & Nederland & 30.2 & België & 29.88 \\
\hline lerland & 40 & Spanje & 35 & Spanje & 35 & Portugal & 28.7 & Slovakije & 29.3 & Slovakije & 29.3 \\
\hline Portugal & 39.6 & Nederland & 34.5 & Nederland & 34.5 & Duitsland & 28.5 & Duitsland & 28.8 & Duitsland & 28.8 \\
\hline Luxemburg & 39.4 & Frankrijk & 34.33 & Frankrijk & 34.33 & Denemarken & 24.5 & Portugal & 27.7 & Portugal & 27.7 \\
\hline Oostenrijk & 39 & Oostenrijk & 34 & Oostenrijk & 34 & Frankrijk & 23.1 & Denemarken & 26.8 & Denemarken & 26.8 \\
\hline Denemarken & 36 & Portugal & 33 & België & 33.99 & Luxemburg & 22.4 & Polen & 26.1 & Polen & 26.1 \\
\hline Spanje & 35.3 & Tsjechië & 31 & Luxemburg & 30.38 & Finland & 21.5 & Spanje & 25.2 & Spanje & 25.2 \\
\hline Griekenland & 35 & Luxemburg & 30.38 & Denemarken & 30 & Griekenland & 21.3 & Luxemburg & 24.5 & Luxemburg & 24.5 \\
\hline Nederland & 35 & Denemarken & 30 & VK & 30 & VK & 19.8 & Finland & 23.5 & Finland & 23.5 \\
\hline Finland & 34.1 & VK & 30 & Finland & 29 & Spanje & 14.4 & Frankrijk & 22 & Frankrijk & 22 \\
\hline Frankrijk & 33.33 & Finland & 29 & Tsjechië & 28 & Oostenrijk & 11.9 & Griekenland & 21 & Griekenland & 21 \\
\hline VK & 33 & Polen & 28 & Zweden & 28 & Ierland & 2 & VK & 20.1 & VK & 20.1 \\
\hline Zweden & 29 & Zweden & 28 & Portugal & 27.5 & & & Zweden & 19.4 & Zweden & 19.4 \\
\hline & & Griekenland & 25 & Estonia & 26 & & & Letland & 18.7 & Letland & 18.7 \\
\hline & & Slovakije & 25 & Griekenland & 25 & & & Oostenrijk & 13.9 & Oostenrijk & 13.9 \\
\hline & & Slovenië & 25 & Slovenië & 25 & & & hongarije & 13.2 & hongarije & 13.2 \\
\hline & & Cyprus & 23 & Polen & 19 & & & lithuania & 11.6 & lithuania & 11.6 \\
\hline & & Letland & 22 & Slovakije & 19 & & & Estonia & 4.8 & Estonia & 4.8 \\
\hline & & hongarije & 18 & hongarije & 16 & & & Tsjechië & 2.4 & Tsjechië & 2.4 \\
\hline & & Ierland & 16 & Letland & 15 & & & Ierland & 2 & Ierland & 2 \\
\hline & & & & Lithuania & 15 & & & & & & \\
\hline & & & & Ierland & 12.5 & & & & & & \\
\hline & & & & Cyprus & 10 & & & & & & \\
\hline gemid. EU15 & 38.51 & gemid. EU23 & 29.54 & gemid. EU25 & 26.80 & gemid. EU15 & 22.82 & gemid. EU23 & 21.52 & gemid. EU23 & 21.48 \\
\hline St. dev. & 7.20 & st.dev. & 6.54 & st.dev. & 8.42 & st.dev. & 9.51 & st.dev. & 11.03 & st.dev. & 10.99 \\
\hline & & gemid. EU10 & 24.57 & gemid. EU10 & 20.8 & & & gemid. EU10 & 15.16 & gemid. EU10 & 15.16 \\
\hline & & st.dev.EU10 & 4.50 & st.dev.EU10 & 7.54 & & & st.dev.EU10 & 10.16 & st.dev.EU10 & 10.16 \\
\hline
\end{tabular}

$\mathrm{a}=$ STRs van Estland, Litouwen en Malta zijn niet beschikbaar voor 2002; b= ETR voor Oostenrijk is de 2001 waarde daar de 2002 waarde niet kon berekend worden; $c$ = ETR= Belasting/Winst voor Belasting; we elimineren firma's met ETRs $>1$ and ETRs $<0$

$\mathrm{d}$ = ETR voor Malta en Cyprus zijn er niet; $\mathrm{e}=$ Zweden kon niet berekend worden; bron: KPMG's corporate tax rate surveys, $\underline{\text { www.worldwide-tax.com }}$

$\mathrm{f}=$ Alleen ETR voor België is op basis van Belfirst-data voor 2003, de ETR van de andere landen is de Amadeus-data van 2002 
Figuur 3: Evolutie van de statutaire aanslagvoet (\%) van 'oude’ en 'nieuwe' EU-

\section{lidstaten}

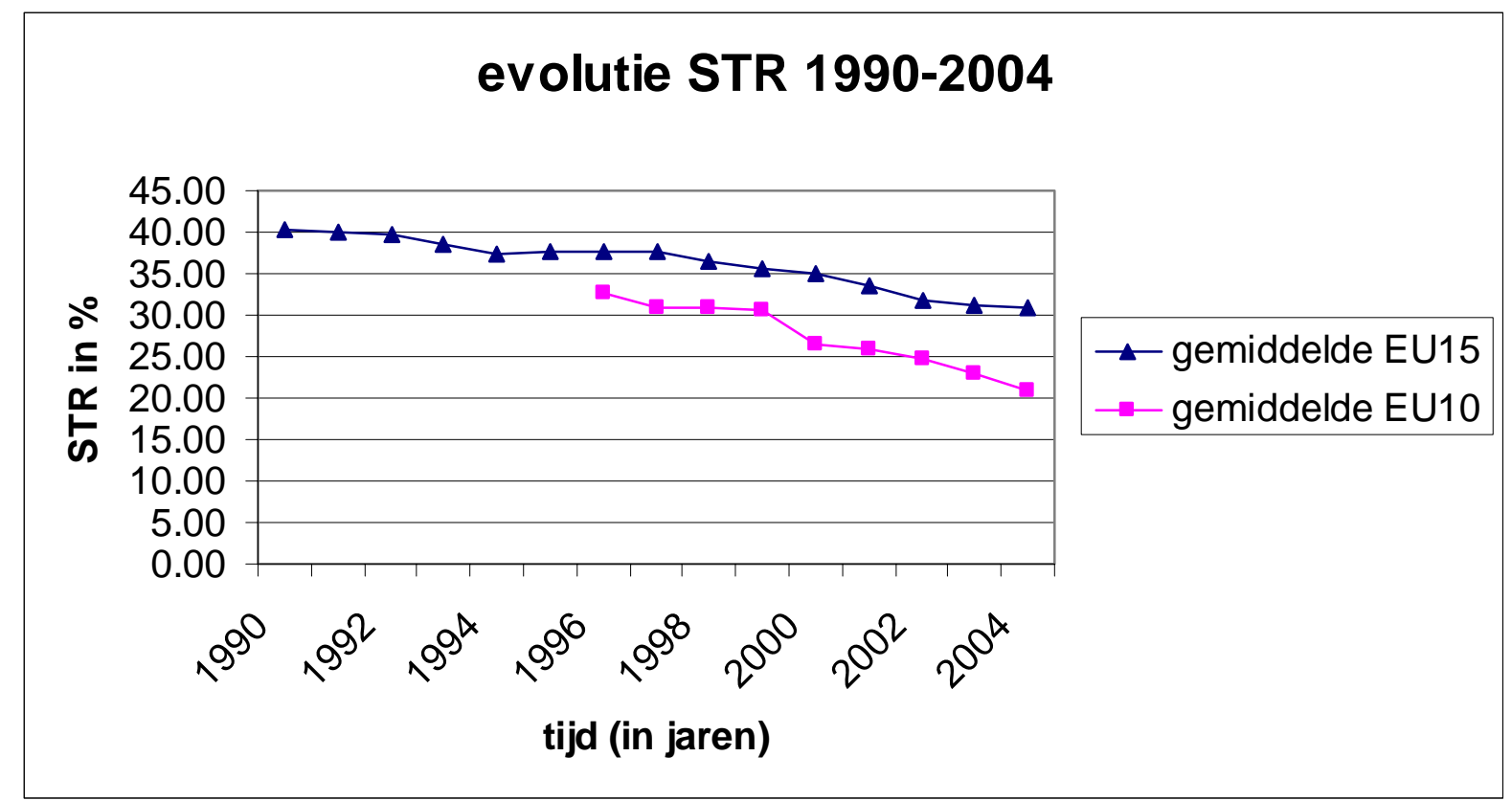

Opm.: data voor STRs van de EU10 is niet beschikbaar voor de periode 1990-1995 EU15 = “oud” Europa ; EU10 = "Nieuwe” EU-lidstaten

Figuur 4: De relatieve evolutie van de statutaire aanslagvoet (\%) voor België

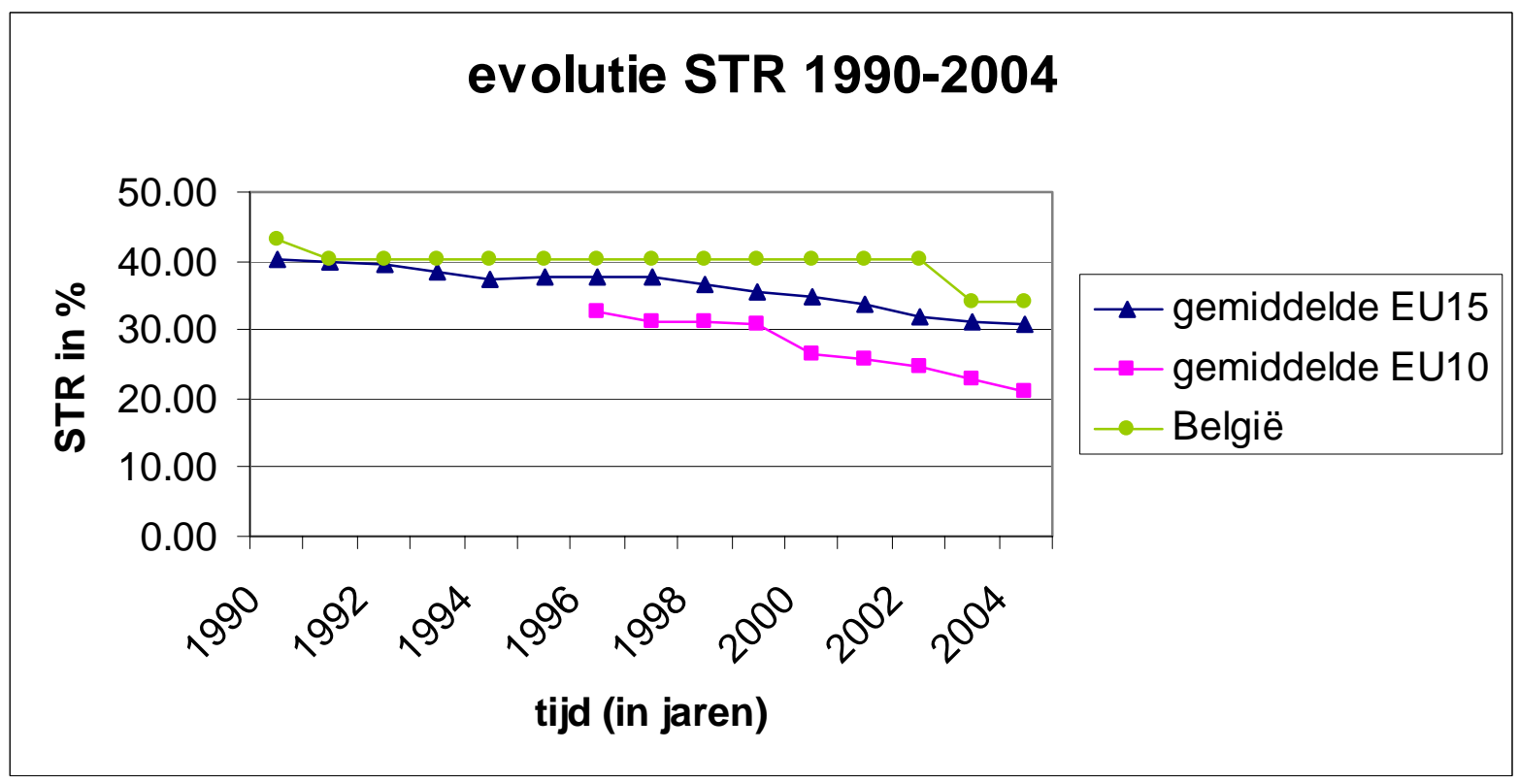

Opm.: data voor STRs van de EU10 is niet beschikbaar voor de periode 1990-1995 EU15 = "oud” Europa ; EU10 = "Nieuwe” EU-lidstaten 
Figuur 5: Evolutie van de effectieve aanslagvoet (\%) van 'oude' en 'nieuwe' EU-

\section{lidstaten}

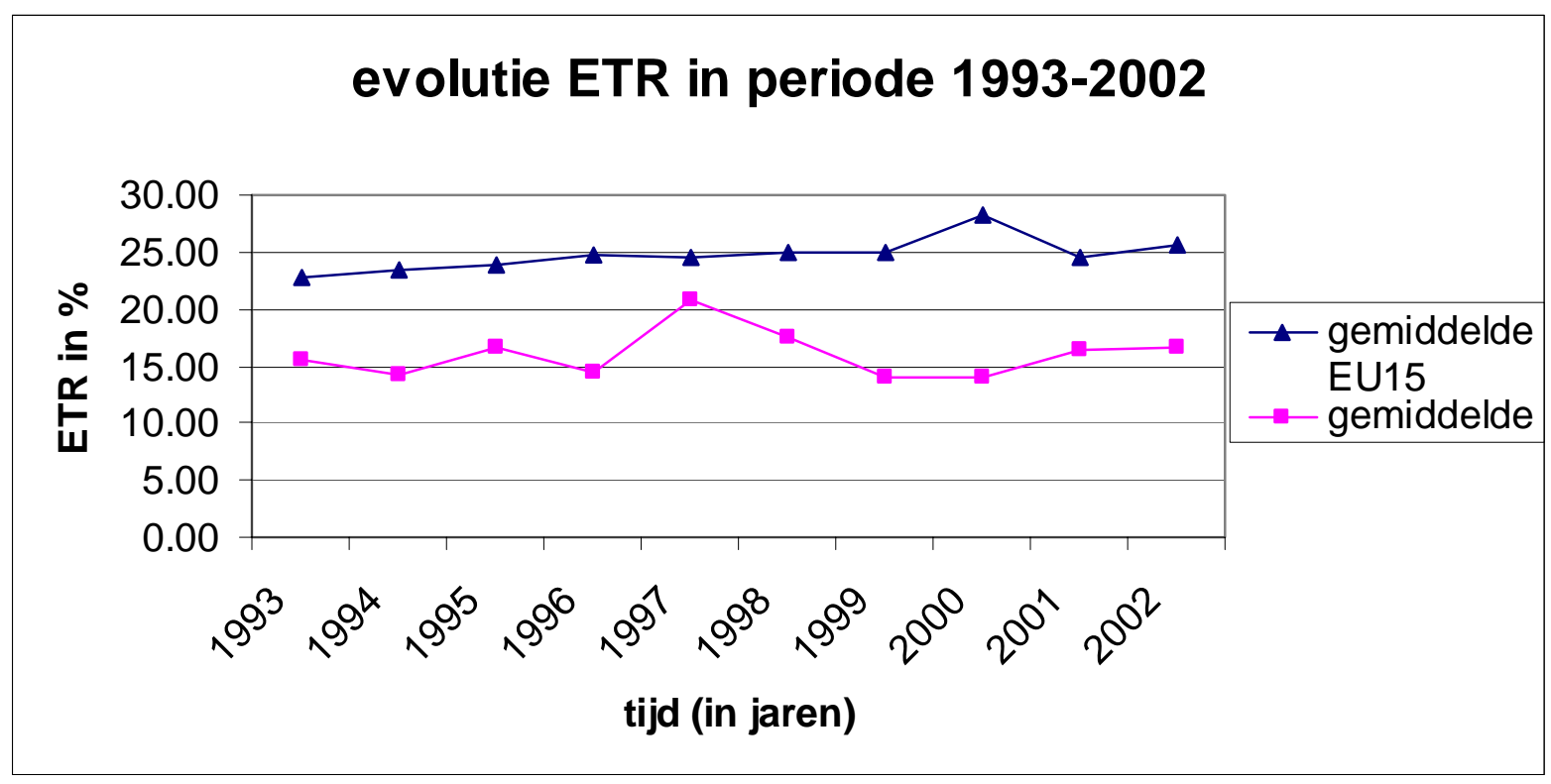

Opm.: $\quad$ Data voor STRs van de EU10 is niet beschikbaar voor de periode 1990-1995 EU15 = "oud" Europa ; EU10 = "Nieuwe" EU-lidstaten

$\mathrm{ETR}=$ Belastingen/Winst voor Belastingen, op basis van firma data van Amadeus 2004

Figuur 6: De relatieve evolutie van de effectieve aanslagvoet (\%) voor België

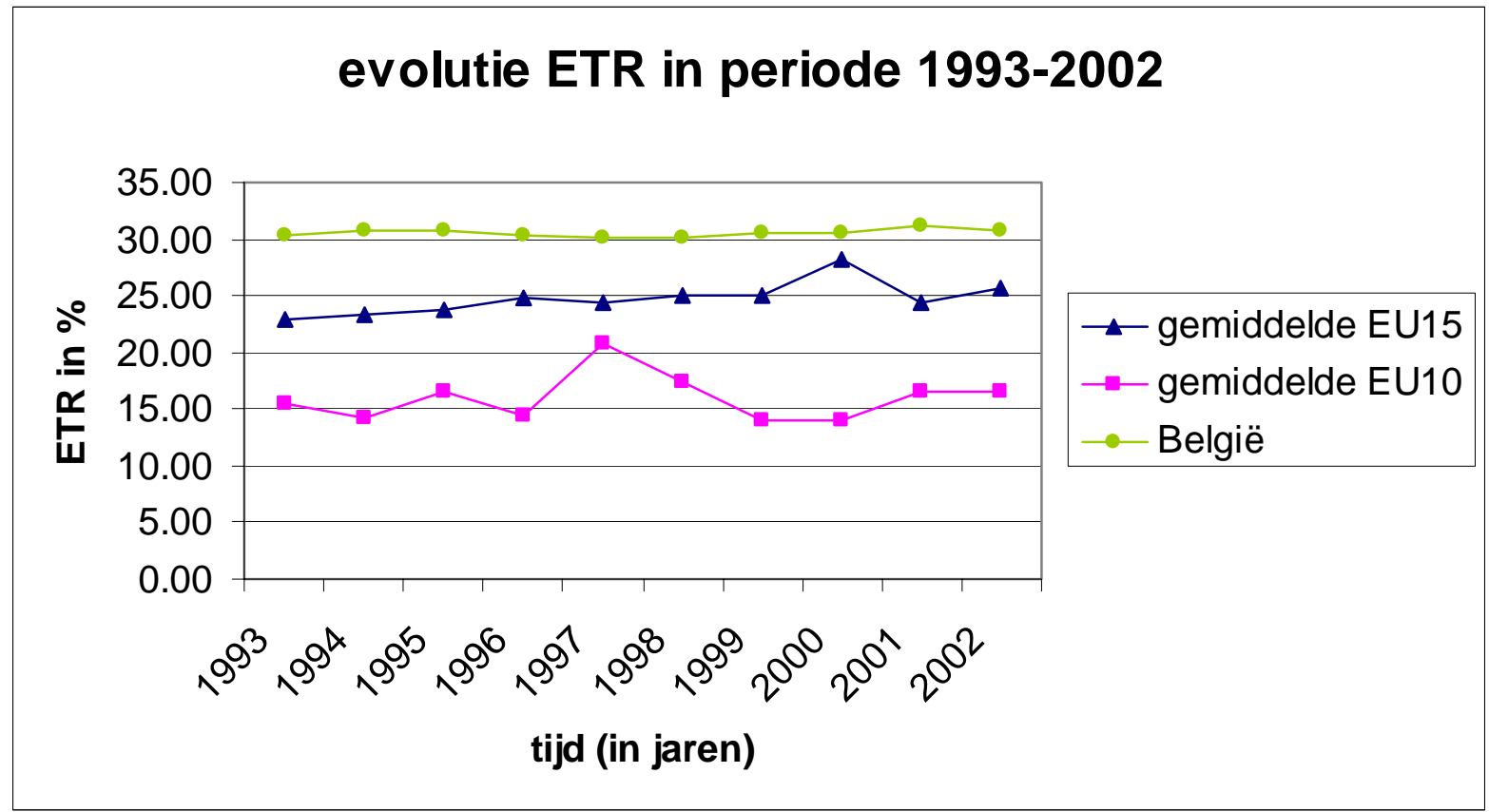

Opm.: $\quad$ Data voor STRs van de EU10 is niet beschikbaar voor de periode 1990-1995 EU15 = "oud" Europa ; EU10 = "Nieuwe” EU-lidstaten

$\mathrm{ETR}=$ Belastingen/Winst voor Belastingen, op basis van firma data van Amadeus 2004 
Figuur 7: Evolutie gemiddelde ETR in België over de periode 1993-2003

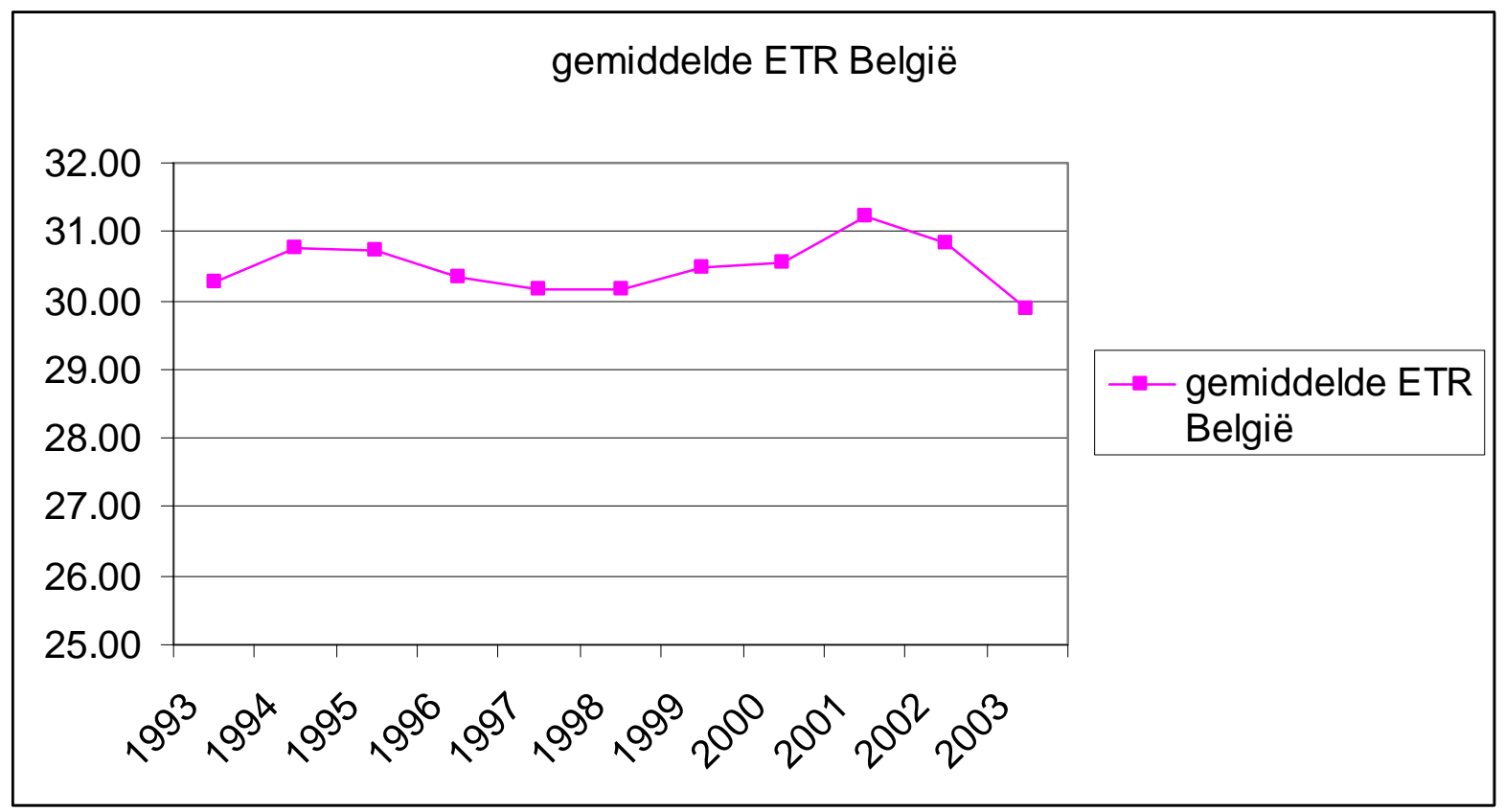

Opm.: gemiddelde ETR 1993-2002 berekend op basis van Amadeus 2004 gegevens, gemiddelde ETR 2003 berekend op basis van Belfirst 2004 gegevens 
Figuur 8: Kaart van het verruimde Europa in 2004

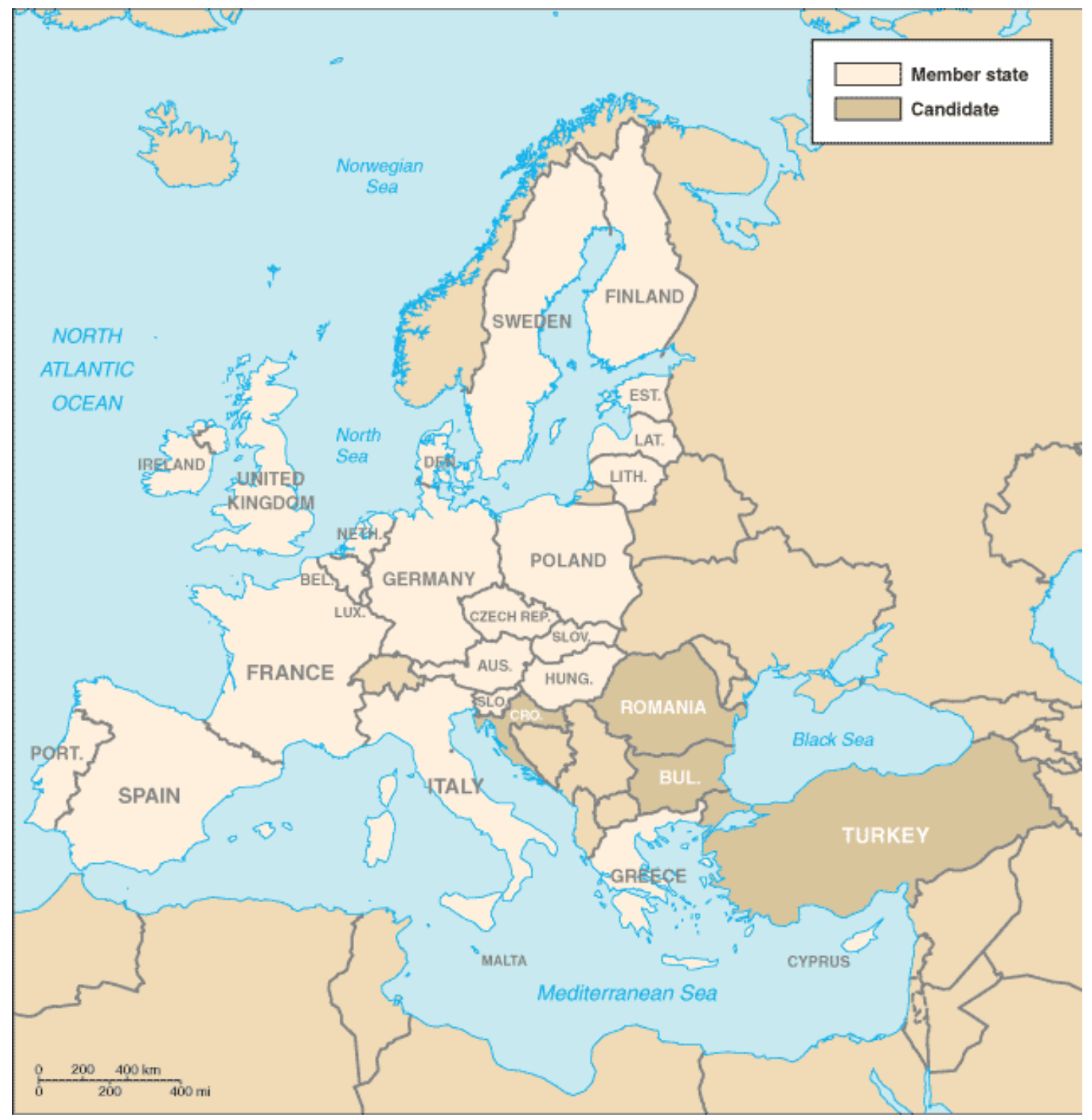

Opm.: 'candidate': de landen die op dit moment geassocieerd zijn met de EU en het lidmaatschap aangevraagd hebben: Bulgarije, Roemenië, Kroatië en Turkije 
Figuur 9: Buren en niet-buren van de nieuwe EU-lidstaten en hun STRs

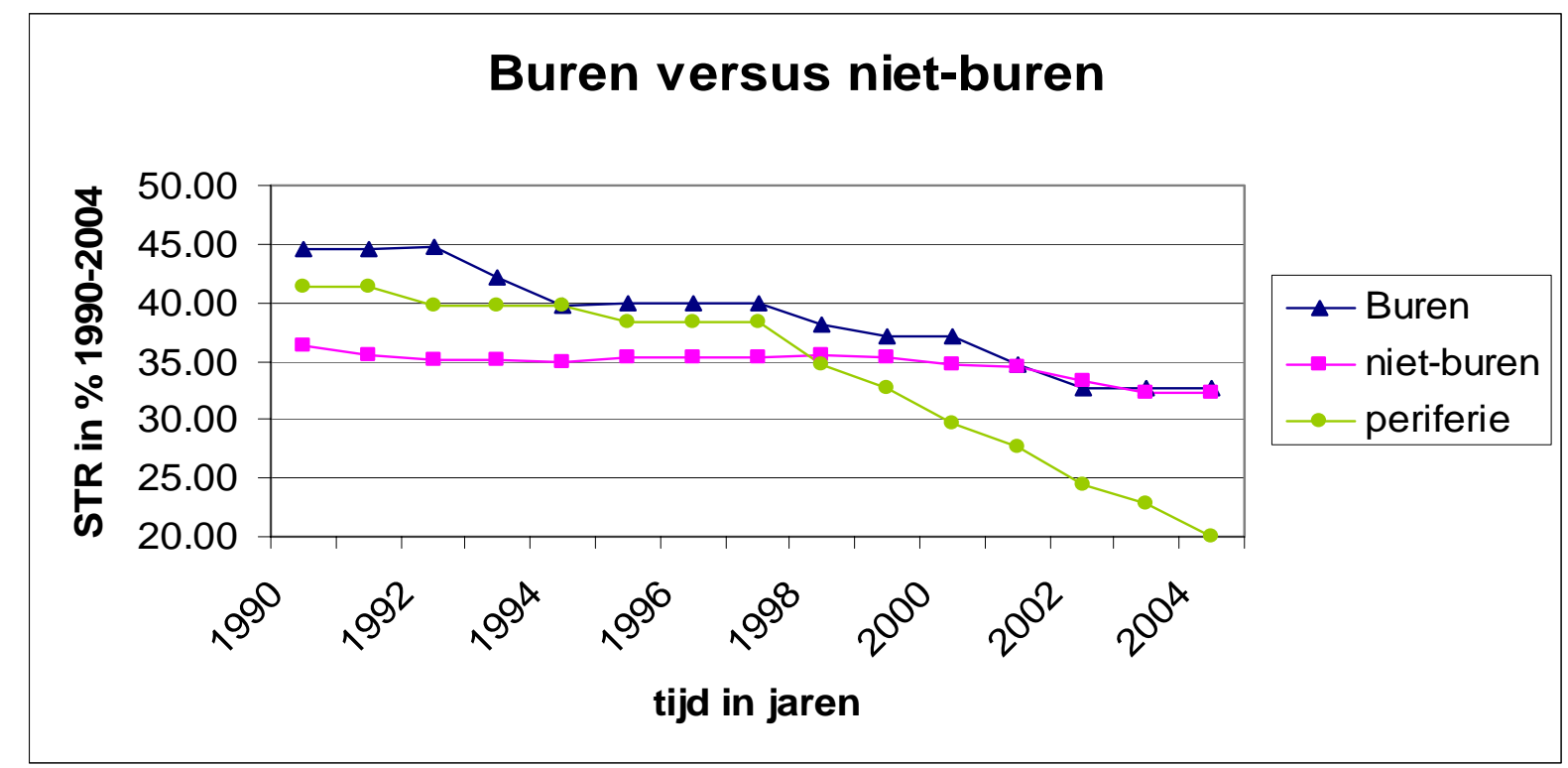

Opm.: Buren (landen van 'oud' Europa die een geografische grens hebben met één van de nieuwe EU landen): Duitsland, Oostenrijk, Denemarken, Finland, Italië en Griekenland Niet-Buren: Spanje, Frankrijk, Verenigd Koninkrijk, Nederland, België, Zweden en Noorwegen

Perifere Niet-Buren: Ierland en Portugal

Figuur 10: Buren en niet-buren van de nieuwe EU-lidstaten en hun STRs

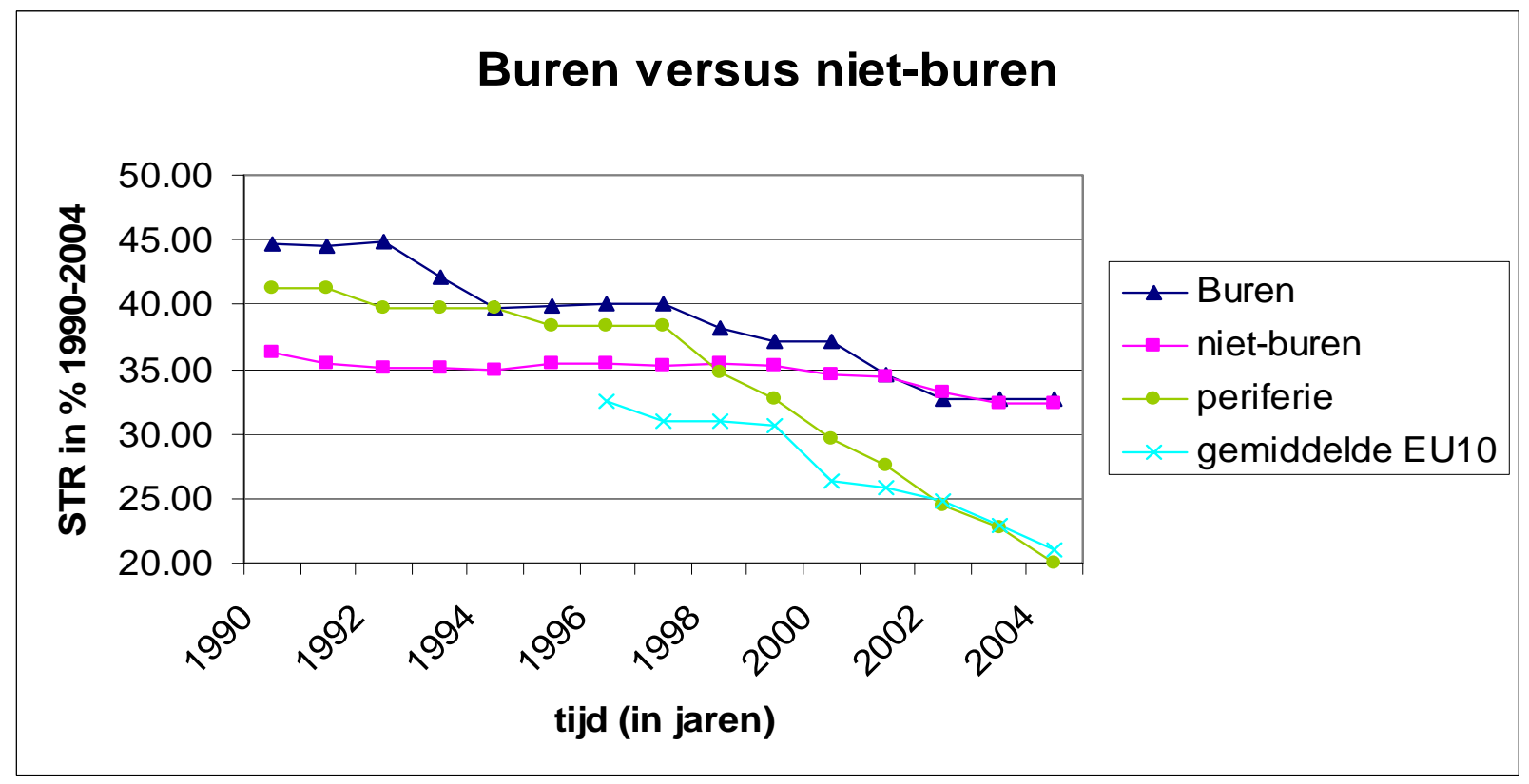

Opm.: Idem Figuur 5

EU10 = 'nieuwe' EU-lidstaten = Polen, Hungarije, Slovakije, Tsjechische Republiek, Slovenië, Letland, Estland, Lithouwen, Malta en Cyprus 


\section{Bibliografie}

Baldwin R. and Krugman P., 2002, Agglomeration, Integration and Tax Harmonization, NBER Working paper series no 9290.

Becker S., Ekholm K., Jäckle R. and Muendler M.A., 2005, Location Choice and Employment Decisions: a Comparison of German and Swedish Multinationals, CEPR discussion paper no 4887

Buijink W., Janssen B., Schols Y., 2000, Corporate effective rates in the EU and the OECD: further research, part 1, 2, 3a, 3b, 3c, Maastricht Accounting and Auditing Research and Education Center

Buijink W., Janssen B., Schols Y., 2002, Evidence of the effect of domicile on corporate average effective tax rates in the European Union, Journal of International Accounting Auditing \& Taxation 11(2002), p 115-130

Collins J. H., Shackelford D.A., 2003, Do U.S. Multinationals face different tax burdens than do other companies?, Tax policy and the economy, vol. 17, issue1, pp141-268

Collins J. H. and Shackelford D.A., 1995, Corporate Domicile and Average Effective Tax Rates: The cases of Canada, Japan, the United Kingdom, and the United States, International Tax and Public Finance, vol. 2, n²1, pp 55-83

Devereux M. P., Griffith R., Klemm A., 2002, Corporate income tax reforms and international tax competition?, economic policy, vol. 35, pp 451-495

Janssen B., 2003, Empirical Evidence on Explicit and Implicit Corporate Tax Burdens, doctoral thesis University of Maastricht

KPMG, 1998, 1999, 2000, 2001, 2002, 2003, 2004, Corporate Tax Survey, KPMG studies 
Nicodème G., 2001, Computing effective corporate tax rates: comparisons and results, DG eocfin, European Commission

Plesko G.A., 2003, An evaluation of alternative measures of corporate tax rates, Journal of Accounting and Economics, vol. 35, pp. 201-226.

Vandenbussche H., Janssen B., Crabbé K., 2005, Regional Tax Competition. Evidence for Belgium, De Economist, Netherland, forthcomming October.

Van Kerckhove en Heirewegh, 2003, Praktisch vennootschapsbelasting, aanslagjaar 2003, (de boeck, Antwerpen)

website: www.worldwide-tax.com

Databanken: Amadeus (2004) en Belfirst (2004) van Bureau Van Dijck

Financial Times, 14 april 2005

De Tijd, 30 april 2005

Trends, 21 april 2005 


\section{Eindnoten:}

${ }^{1}$ inclusief het solidariteitstarief en handelsbelasting.

${ }^{2}$ buren: Duitsland, Oostenrijk, Denemarken, Finland, Italië en Griekenland; niet-buren: Spanje, Frankrijk, Verenigd Koninkrijk, Nederland, België, Zweden en Noorwegen

${ }^{3}$ Met een niet-progressief systeem bedoelen we een systeem waarbij alle bedrijven ongeacht hun belastbare winst aan eenzelfde statutair tarief onderworpen zijn.

${ }^{4}$ Voor België is dit voor bedrijven met een jaarlijkse belastbare winst (belastingsbasis) van meer dan 323.750 Euro (Van Kerchove \& Heirewegh, 2003,Vennootschapsbelasting-praktisch)

${ }^{5}$ We gebruiken hiervoor de meest recente gegevens ter onzer beschikking. Voor de officiële aanslagvoeten zijn dat verschillende bronnen zoals Janssen (2003), KPMG studies (1998-2005) en www.worldwide-tax.com, terwijl voor wat betreft de feitelijke belastingdruk (ETR) we ons baseren op firma-gegevens van de databasis

AMADEUS waar de recentste die in ons bezit zijn van 2 jaar eerder dateren namelijk van 2002.

${ }^{6} 40.17 \%$ is van toepassing op bedrijven met een belastbare winst (basis) vanaf $323.750 €$.

${ }^{7}$ inclusief de crisisbelasting

${ }^{8}$ In navolging van Collins \& Schackelford $(1995,2003)$, bekijken we enkel de firma’s waarvoor de ETR maatstaf tussen redelijke waarden ligt namelijk tussen 0 en 1.

${ }^{9}$ De Amadeus gegevens zijn maar ter beschikking tot en met 2002.

${ }^{10}$ De hoogste belastingsschaal voor bedrijven is vergroot naar alle bedrijven met een belastbare basis groter dan 322261.59 euro 